\title{
DAMPAK INOVASI PEMBELAJARAN BERBASIS KARAKTER TERHADAP PENGEMBANGAN KARAKTER POSITIF DI SD KARAKTER GENIUS ISLAMIC SCHOOL KOTA DEPOK
}

\author{
Susanto ${ }^{1}$ \\ ${ }^{1}$ Institut PTIQ, Jakarta \\ *Corresponding Address: susanto@ptiq.ac.id
}

Naskah diterima: 1 November 2021| Disetujui: 9 November 2021 | Diterbitkan: 16 November 2021

\begin{abstract}
This study uses a qualitative research approach with data collection techniques using interviews, observations and literature review. Character-based learning innovations at the Genius Islamic School Character Elementary School are designed, developed and structured dynamically by the teachers by prioritizing noble character values based on local wisdom. The development of character-based learning at SD Character Genius Islamic School is carried out through various strategies including implementing Seven Core Values or 7 (seven) pillars of character in every learning and civilizing process in the school environment including: religious pillars, discipline, empathy, respect, integrity, critical thinking and self-regulated learning. Character-based learning innovations developed by the teachers at the Character Genius Islamic School have a positive impact on the character development of students. With the highest results obtained, namely in the aspects of Religion Belief and Critical Thinking with an achievement of 97\%. This shows that teachers have succeeded in internalizing religious values to students, are able to form independent learning and innovate.
\end{abstract}

Keywords: learning innovation, character education, religious, integration

\begin{abstract}
Abstrak: Penelitian ini bertujuan untuk menganalisis dampak dari inovasi pembelajaran berbasis karakter terhadap perkembangan karakter positif di Sekolah Dasar (SD) Karakter Genius Islamic School kota Depok. Penelitian ini menggunakan pendekatan penelitian kualitatif dengan teknik pengumpulan data wawancara, observasi, dan kajian pustaka. Inovasi pembelajaran berbasis karakter di SD Karakter Genius Islamic School dirancang, dikembangkan dan disusun secara dinamis oleh para guru dengan mengedepankan nilai-nilai karakter luhur berbasis pada kearifan lokal. Pengembangan pembelajaran berbasis karakter di SD Karakter Genius Islamic School dilakukan melalui berbagai strategi di antaranya menerapkan Seven Core Values atau 7 (tujuh) pilar karakter dalam setiap proses pembelajaran dan pembudayaan di lingkungan sekolah meliputi pilar religious, discipline, empathy, respect, integrity, critical thinking dan self regulated-learning. Inovasi pembelajaran berbasis karakter yang dikembangkan oleh para guru di SD Karakter Genius Islamic School berdampak positif bagi perkembangan karakter siswa. Dengan hasil tertinggi yang diperoleh yaitu pada aspek Religion Belief dan Critical Thinking dengan pencapaian sebanyak 97\%. Hal tersebut menunjukkan bahwa para guru berhasil menginternalisasikan nilai-nilai keagamaan kepada para siswa, mampu membentuk kemandirian belajar, dan berinovasi.
\end{abstract}

Kata kunci: inovasi pembelajaran, pendidikan karakter, religius, integrasi 


\section{PENDAHULUAN}

Pendidikan karakter menjadi perbincangan hangat dalam dunia pendidikan saat ini, hal tersebut bukanlah tanpa dasar, menengok beberapa kejadian yang marak terjadi beberapa tahun terakhir di negara ini dengan banyaknya kasus korupsi, suap, tindak kekerasan, pergaulan bebas, serta mulai menurunnya sikap-sikap luhur seperti kesantunan, kejujuran, tanggung jawab, dan tindak amoral lainnya (Husni, 2020). Beberapa kasus tidak hanya terjadi pada golongan manusia dewasa saja akan tetapi juga banyak terjadi pada anak-anak dan remaja. Perilaku-perilaku menyimpang tersebut tentunya menurunkan karakter bangsa. Pada zaman modern saat ini, globalisasi telah melahirkan budaya-budaya modern yang mengarah pada liberalisasi, rasionalisasi, dan efisiensi (Abu et al., 2015). Menurut Azyumardi Azra budaya modern secara terus menerus menggerus kehidupan spiritual umat manusia, yang mengakibatkan keringnya spiritualitas (Azra, 2019). Keringnya nilai spiritual ternyata memiliki dampak terhadap warga masyarakat, mereka merasa kehilangan pegangan hidup yang kebanyakan dialami oleh kalangan muda. Hal tersebut menjadikan masyarakat terjerumus dalam perbuatan-perbuatan negatif (Tutuk, 2015).

Langkah strategis yang diambil untuk menanggulangi krisis tersebut dapat ditempuh melalui berbagai strategi, salah satunya melalui pendidikan di sekolah atau pendidikan luar sekolah (Saidek \& Islami, 2016). Dalam pelaksanaannya, upaya yang ditempuh melalui jalur sekolah tentunya memerlukan perubahan cara pandang terhadap proses pembelajarannya yang berbasis pendidikan karakter. Pendidikan karakter merupakan sebuah proses yang dilakukan untuk mengembangkan peserta didik demi sebuah kesadaran sebagai warga bangsa yang bermartabat, merdeka dan berdaulat, serta berkemauan untuk menjaga dan mempertahankan kemerdekaan kedaulatan tersebut (Ningsih et al., 2015). Pendidikan karakter merupakan sebuah langkah untuk mengembangakan pendidikan dalam mengatasi permasalahan karakter di Indonesia. Hal ini senada dengan pernyataan Marzuki tentang integrasi pendidikan karakter dalam pembelajaran di sekolah yang mengatakan bahwa, "Pendidikan karakter adalah sebuah upaya dalam sebuah proses pembelajaran yang dilakukan untuk menginternalisasikan kebiasaan-kebiasaan baik yang harus dimengerti dan dipahami oleh peserta didik, sehingga peserta didik tersebut dapat menerapkan dalam kehidupan sehari-hari” (Khusniati, 2012). Sebagai generasi penerus bangsa, anak-anak dan remaja merupakan objek dari rekontruksi karakter bangsa. Di sinilah dunia pendidikan mendapatkan tanggung jawab yang sangat besar dalam internalisasi nilai-nilai karakter khususnya sekolah dasar menjadi basis internalisasi karakter dalam jenjang pendidikan formal (Zuchdi et al., 2010). Tujuan pendidikan karakter pada intinya adalah untuk membentuk bangsa yang tangguh, bermoral, berakhlak mulia, bertoleren, bergotong-royong, berjiwa patriotik, berorientasi ilmu pengetahuan teknologi yang semuanya dijiwai oleh iman dan taqwa kepada Tuhan Yang Maha Esa berdasarkan Pancasila (Djazilan et al., 2021) 
Dalam hal implementasi pendidikan karakter di Indonesia ada beberapa acuan yang digunakan. Pertama adalah Undang-Undang Republik Indonesia Nomor 20 tahun 2003 tentang sistem pendidikan nasional yang menyatakan bahwa pendidikan nasional berfungsi mengembangkan kemampuan dan membentuk watak serta peradaban bangsa yang bermartabat dalam rangka mencerdaskan kehidupan bangsa, bertujuan untuk berkembangnya potensi peserta didik agar menjadi manusia yang beriman dan bertakwa kepada Tuhan Yang Maha Esa, berakhlak mulia, sehat, berilmu, cakap, kreatif, mandiri, dan menjadi warga negara yang demokratis serta bertanggung jawab (Sani, 2013)..

Acuan kedua adalah Peraturan Menteri Agama Nomor 2 Tahun 2020 Tentang Penyelenggaraan Penguatan Pendidikan Karakter yang berbunyi bahwa penguatan pendidikan karakter yang selanjutnya disingkat PPK adalah gerakan pendidikan di bawah tanggung jawab satuan pendidikan untuk memperkuat karakter peserta didik melalui harmonisasi olah hati, olah rasa, olah pikir, dan olah raga dengan pelibatan dan kerja sama antara satuan pendidikan, keluarga, dan masyarakat sebagai bagian dari gerakan nasional revolusi mental. Penyelenggaraan PPK mempunyai tujuan untuk peningkatan penerapan nilai-nilai agama dan pancasila dalam pendidikan agama dan pendidikan keagamaan. Dengan melihat karakter bangsa saat ini, dapat dikatakan bahwa tujuan pendidikan yang telah ditetapkan dalam Undang-Undang Republik Indonesia Nomor 20 tahun 2003 tentang Sistem Pendidikan Nasional dan tujuan pendidikan karakter belumlah tercapai

Menurut hasil penelitian yang dilakukan oleh Lynn \& Arthur, dikatakan bahwa pendidikan di Indonesia secara garis besar berorientasi pada hasil ujian. Oleh sebab itu, sudah saatnya sistem pendidikan di Indonesia ditata ulang dan dikembangkan dalam rangka memenuhi tuntutan zaman yang kian maju dan berkembang. Dari sini dapat dilihat apa penyebab dari kesalahan proses pembelajaran dan evaluasi yang berlangsung selama ini sehingga menciptakan generasi yang rapuh, mudah emosi, dan kehilangan karakternya (Revell \& Arthur, 2007). Praktek pendidikan di Indonesia dirasa belum mampu membangun kemampuan peserta didik yang seimbang. Pelaksanaan pendidikan saat ini cenderung meningkatkan kemampuan otak kiri daripada otak kanan (Hidayat, 2016). Materi pembelajaran yang bersinggungan langsung dengan peningkatan karakter positif siswa seperti nilai moral dan nilai agama dalam prakteknya lebih ditekankan pada aspek hafalan tanpa melihat bagaimana pemahaman anak-anak terhadap materi yang telah dipelajari (Suwardani, 2020).

Implementasi nilai karakter bukan hanya sekadar teori yang mengajarkan kepada kita tentang mana yang baik dan mana yang buruk. Implementasi nilai karakter merupakan sebuah upaya untuk menanamkan nilai-nilai yang positif, sehingga anak menjadi mengerti, menghayati, kemudian menimbulaka sebuah dorongan untuk melakukan sesuatu yang positif (Rasna \& Tantra, 2017). Maka 
dari itu, pendidikan karakter diharapkan mampu memecahkan permasalahan-permasalahan moral bangsa (Fahmi \& Prasetia, 2021). Internalisasi nilai-nilai karakter, menurut Ki Hadjar Dewantara tahun 1962, yakni olah hati atau etika, olah pikir atau literasi, olah karsa atau estetika, dan olah raga atau kinestetika (Komara, 2018). Dalam prosesnya, setidaknya nilai-nilai tersebut diperinci menjadi delapan belas nilai yang harus ditanamkan kepada anak-anak. Kedelapan belas nilai tersebut adalah religius, jujur, toleransi, disiplin, kerja keras, kreatif, mandiri, demokratis, rasa ingin tahu, semangat kebangsaan, cinta tanah air, menghargai prestasi, bersahabat/komunikatif, cinta damai, gemar membaca, peduli lingkungan, peduli sosial, dan tanggung jawab (Murniyetti et al., 2016).

Dari penjelasan di atas dapat diketahui bahwa penanaman nilai-nilai karakter dapat dilakukan melalui tripusat pendidikan. Dalam hal ini, pusat pendidika yang dianggap strategis untuk pelaksanaan pendidikan karakter adalah sekolah, tentu dalam persoalan pendidikan karakter tidak bisa dibebankan kepada sekolah saja, namun pendidikan karakter juga merupakan tanggung jawab keluarga dan masyarakat. Sekolah sebagai salah satu tempat yang strategis karena pendidikan berlangsung dari berbagai lapisan dan jenjang (Hartono et al., 2018); (Hidayat, 2016).

Pendidikan karakter yang berlangsung di lingkungan sekolah diartikan sebagai sebuah proses belajar mengajar yang diarahkan kepada pemupukan dan pengukuhan perilaku siswa dengan menyeluruh berdasar pada standar yang telah ditentukan oleh pihak lembaga. Pengertian ini mengandung beberapa makna, di antaranya sebagai berikut.

1. Pendidikan karakter adalah pendidikan yang terintegrasi pada proses pembelajaran yang diterapkan di setiap mata pelajaran.

2. Pendidikan karakter diarahkan pada pemupukan dan pengukuhan perilaku anak secara menyeluruh.

3. Pendidikan karakter diarahkan pada pemupukan dan pengukuhan perilaku nilai yang dirujuk sekolah (Julaeha, 2019).

Ada dua faktor utama yang berpengaruh pada proses internalisasi nilai karakter di lingkungan sekolah, yaitu faktor intern dan faktor ekstern. Faktor intern sekolah meliputi peran stake holder, peraturan sekolah, adanya silabus, kurikulum, integritas siswa, kedisiplinan guru, profesionalisme guru, sarana prasarana sekolah yang mendukung, visi dan misi sekolah, kedisiplinan peserta didik, integritas karyawan, adanya punishment dan komitmen warga sekolah terhadap pembinaan dan pendidikan karakter bangsa. Sedangkan faktor ekstern sekolah antara lain, kondisi lingkungan pendidikan, kebiasaan masyarakat sekitar, lingkungan keluarga, dan peran tokoh masyarakat (Tutuk, 2015); (Suherman et al., 2019). 
Menurut Kemendiknas, dalam proses internalisasi nilai karakter positif di sekolah, perlu adanya integrasi nilai-nilai karakter terhadap seluruh materi pelajaran. Hal tersebut dilakukan untuk mengembangkan keterlibatan antara materi pelajaran dengan karakter itu sendiri (Kemendiknas, 2010). Upaya lainnya dengan memastikan apakah proses pembelajaran tersebut memiliki dampak dalam mengkonstruksi karakter. Proses integrasi satu nilai tentunya dapat dilakukan untuk semua materi pelajaran. Secara internal setiap nilai mengandung elemen pikiran, perasaan dan perilaku moral yang secara psikologis saling berinteraksi (Izzati et al., 2019).

Bersandar terhadap pendapat Ahmad Tafsir bahwa proses integrasi nilai karakter dalam proses pembelajaran bisa menggunakan berbagai macam metode, seperti (a) dengan mengintegrasikan materi pelajaran, (b) mengintegrasikan proses, (c) mengintegrasikan bahan ajar, dan (4) mengintegrasikan media pembelajaran (Tafsir, 2009); (Faujiah et al., 2018). Lain halnya dengan pendapat Endah Sulistyowati, bahwa prinsip internalisasi nilai karakter ialah keaktifan siswa. Untuk merangsang keaktifan siswa, maka guru diwajibkan membuat perencanaan pengajaran dengan memformulasikan pertanyaan, mencari sumber informasi, mengumpulkan informasi, mengolah informasi yang sudah dimiliki, merekonstruksi data, fakta, atau nilai, dan menyajikan hasil rekonstruksi atau proses pengembangan nilai (Sulistyowati, 2012).

Proses pendidikan karakter tentunya bukan hanya menjadi tugas seorang guru agama saja, akan tetapi ini merupakan tugas dan kewajiban semua guru. Guru memiliki peran untuk menentukan perencanaa sebuah pembelajaran yang akan dilakukan (Suharsaputra, 2010); (Eka, 2017). Di sini keahlian yang dimiliki guru sangat dipelukan seperti keahlian dalam bidang perencanaan, manajemen dan pengajaran. Perencanaan yang dimaksud adalah penciptaan kondisi kesiapan aktivitas kelas, satuan acara pembelajaran, media dan sumber pembelajaran, serta pengorganisasian lingkungan belajar (Danim, 2002). Untuk mewujudkan bangsa yang berkarakter, maka seorang guru dituntut untuk menciptakan inovasi pembelajaran yang efektif dan efisien untuk menanamkan nilai-nilai karakter.

Dalam perjalanannya, proses internalisasi nilai karakter di sekolah kian mendapatkan tantangan, hal tersebut tidak terlepas dari permasalahan-permasalahan berikut: (1) kurikulum tidak dijadikan standar tetap; (2) hanya dijadikan sebuah wacana tanpa realisasi; (3) tidak adanya koordinasi/kerjasama antara pelaksanaan penguatan pendidikan karakter di sekolah dan lingkungan keluarga; (4) kurangnya peran guru dalam pelaksanaan pembelajaran karakter di sekolah (Supriati \& Umar, 2018). Pendidikan karakter yang menjadi sorotan pemerintah dan para pendidik merupakan program baru yang diprioritaskan Kementrian Pendidikan dan Kebudayaan. Sebagai program baru, tentunya menghadapi banyak masalah dan kendala. Kendala-kendala tersebut di antaranya: (1) Nilai- 
nilai karakter yang dikembangkan di sekolah belum terjabarkan dalam indikator yang representatif; (2) Sekolah belum memilih nilai-nilai karakter yang sesuai dengan visinya; (3) Pemahaman guru tentang konsep pendidikan karakter yang masih belum menyeluruh; (4) Guru belum dapat memilih nilai-nilai karakter yang sesuai dengan mata pelajaran yang diampunya; (5) Guru belum memiliki kompetensi yang memadai untuk mengintegrasikan nilai-nilai karakter pada mata pelajaran yang diampunya; dan (6) Guru belum dapat menjadi teladan atas nilai-nilai karakter yang dipilihnya (Judiani, 2010).

Pendidikan Karakter cenderung tak akan pernah tersentuh secara nyata, jika ada hanya sebatas proses pemahaman tentang karakter atau hanya bersifat informasi tanpa adanya tindakan. Konsep karakter tidak cukup dijadikan sebagai suatu poin dalam silabus dan rencana pelaksanaan pembelajaran di sekolah, namun harus dijalankan dan dipraktekkan. Pendidikan karakter merupakan sebuah proses (step by step). Kunci dari pendidikan karakter adalah disiplin, komitmen, dan penerapan. Pendidikan Karakter tidak hanya diberikan secara teoritik di sekolah, namun juga perlu diterapkan dalam kehidupan sehari-hari, dan akan akan menjadi kebiasaan (Gunawan, 2012). Menurut Ahmad Tafsir, integrasi pendidikan karakter dalam proses pembelajaran dapat dilakukan dengan berbagai cara, seperti mengintegrasikan materi pelajaran, mengintegrasikan proses, mengintegrasikan bahan ajar, dan mengintegrasikan media pembelajaran (Faujiah et al., 2018).

Berkaitan dengan upaya dalam memperbaiki karakter bangsa Indonesia, SD Karakter Genius Islamic School, merupakan salah satu lembaga pendidikan yang mengembangkan pembelajaran berbasis karakter. Dalam mewujudkan visi dan misi dari lembaga ini, maka dikembangkan pembelajaran berbasis karakter di mana hal tersebut dilakukan melalui berbagai strategi. Strategi yang diterapkan disebut dengan Seven Core Values atau 7 (tujuh) pilar karakter. Ketujuh pilar tersebut diterapkan dalam setiap proses pembelajaran dan pembudayaan di lingkungan sekolah meliputi pilar religious, discipline, empathy, respect, integrity, critical thinking dan self regulated-learning. Berdasarkan data yang telah dikumpulkan, maka penelitian ini bermaksud untuk menganalisis dampak dari inovasi pembelajaran berbasis karakter terhadap perkembangan karakter positif di SD Karakter Genius Islamic School Kota Depok.

\section{METODE}

Penelitian ini menggunakan pendekatan penelitian kualitatif. Teknik pengumpulan data menggunakan teknik wawancara, observasi, dan studi pustaka. Wawancana peneliti dilakukan dengan direktur pendidikan, kepala sekolah, serta guru. Observasi dilakukan untuk mengetahui perkembangan karakter peserta didik dengan mengacu pada 7 (tujuh) pilar karakter yang 
dikembangkan di sekolah berbasis karakter genius Islamic School depok. Sementara studi pustaka bersumber character report guru, character report orangtua serta dokumen terkait. Penelitian dilaksanakan selama 4 bulan mulai Februari-Juni 2021. Peserta didik yang dijadikan subyek penelitian berjumlah 40 siswa, dengan rincian masing-masing level berjumlah 10 peserta didik dari kelas 1 sampai kelas 4.

\section{HASIL DAN PEMBAHASAN}

\section{Strategi Pendidikan Karakter di SD Karakter Genius Islamic School}

SD Karakter Genius Islamic School meupakan salah satu satuan pendidikan dengan jenjang SD di Sukamaju, Kecamatan Cilodong, Kota Depok, Jawa Barat. Dalam menjalankan kegiatannya, SD Karakter Genius Islamic School berada di bawah naungan Kementerian Pendidikan dan Kebudayaan yang didirikan pada tahun 2013 dengan konsep yang khas, memiliki visi besar dan terus melakukan inovasi agar mampu menjawab kebutuhan berbagai tantangan di abad ke-21. Abad ini memerlukan insan cerdas, religius, kreatif, kritis, imajinatif (problem solver), mandiri, aspiratif, beretos kerja tinggi, adaptif serta berani mencoba dan menciptakan inovasi-inovasi baru sesuai tahapan usianya. Berdasarkan rekap data per tanggal 25 Oktober 2021, jumlah siswa sebanyak 239 siswa (Genius Islamic School, 2021).

Visi dari SD Karakter Genius Islamic School adalah religius, berkarakter unggul, berdaya saing tinggi, dan berwawasan global. Misi dari SD Karakter Genius Islamic School antara lain:

1. Mendidik anak dengan kasih sayang untuk mewujudkan generasi Qur'ani, berkarakter unggul, dan berwawasan global.

2. Menyelenggarakan pembelajaran holistik berbasis karakter, kreatif, inovatif, dan menyenangkan untuk semua anak dengan beragam potensinya.

3. Menggali, mengembangkan, dan mengoptimalkan potensi dan bakat anak untuk mencapai prestasi unggul dan berdaya saing.

Dalam mewujudkan visi dan misinya, seluruh aktifitas pembelajaran selalu diarahkan untuk menumbuhkan dan membiasakan nilai-nilai karakter unggul, meliputi religious, disclipine, self regulated learner, critical thinking, integrity, respect, dan empathy (Genius Islamic School, 2021). Dalam hal ini, inovasi yang dikembangakan oleh SD Karakter Genius Islamic School dalam membentuk karakter positif siswa adalah strategi pembelajaran berbasis karakter. Strategi tersebut dilakukan melalui 5 (lima) upaya, yaitu: 
1. Integrasi nilai-nilai karakter dalam materi pelajaran.

a. Mengintegrasikan nilai-nilai karakter dalam materi ajar melalui 3 tahapan, yaitu analisis kebutuhan, integrase, dan evaluasi.

b. Integrasi melalui tematik, islamic studies, tahfidz, science, english, math, Bahasa Sunda baik secara eksplisit maupun implisit.

c. Pola integrasi menggunakan 3 (tiga) upaya, yaitu secara eksplisit nilai karakternya dalam kompetensi dasar, disisipkan nilai karakternya tanpa muncul dalam kompetensi dasar, dan disisipkan melalui metode/contoh yang relevan.

2. Integrasi karakter positif melalui pemilihan metode yang edutainment berwawasan karakter.

Strategi pembelajaran edutainment berbasis karakter dapat diterapkan dengan menggunakan berbagai model pembelajaran. Model-model pembelajaran yang dipilih hendaknya memenuhi syarat-syarat sebagai berikut:

a. Berorientasi pada materi yang akan dipelajari dan sesuai jika diterapkan.

b. Mengandung unsur hiburan sehingga menyenangkan bagi peserta didik.

c. Memuat penanaman nilai-nilai karakter.

Nilai-nilai karakter yang ingin dikembangkan oleh SD Karakter Genius Islamic School harus tercantum pada perencanaan pembelajaran. Dalam hal ini, guru dituntut untuk lebih cermat dalam memunculkan nilai-nilai karakter yang ditargetkan dalam setiap proses pembelajaran. Nilai-nilai karakter tersebut harus tertulis jelas pada tujuan pembelajaran. Pada langkah-langkah pembelajaran juga harus memfasilitasi peserta didik untuk memperoleh pengetahuan dan keterampilan yang ditargetkan dan mengembangkan karakter yang sebelumnya tertuang pada tujuan pembelajaran

3. Melalui character education selama 10 menit dalam rangkaian apersepsi yang mengandung muatan 7 pilar karakter yang dikembangkan di SD Genius Islamic school. Character education ini diberikan kepada anak sebelum materi pembelajaran berlangsung. Pada saat apersepsi, guru mengucapkan salam, membuka kegiatan pembelajaran, mengawali dengan yel-yel positif, menyanyi, dan lainnya sejalan dengan muatan karakter positif. Selanjutnya, guru memberikan materi character education selama 10 menit melalui berbagai strategi, di antaranya melalui video karakter disesuaikan dengan jadwal pilar karakter yang ingin dikembangkan pada minggu dan bulan tertentu, melalui diskusi problem solving, studi kasus, dan berbagai metode lainnya.

4. Melalui komunikasi berwawasan karakter dalam proses pembelajaran dan interaksi di lingkungan sekolah dengan memperhatikan sejumlah aspek, yaitu; 
a. Kejelasan pesan, dalam komunikasi harus menggunakan bahasa dan mengemas informasi secara jelas, mudah diterima dan dipahami oleh anak.

b. Ketepatan pesan, ketepatan penggunaan bahasa/diksi/kalimat dan sesuai nilai-nilai karakter positif dan nilai-nilai Islam.

c. Kesesuaian pesan yang disampaikan sesuai tahapan, usia dan perkembangan anak;

d. Alur bahasa/kalimat yang digunakan harus sistematis.

e. Orientasi, setiap kata dan kalimat yang dipilih bermuatan positif untuk pembentukan karakter anak

f. Tidak mengandung stigmatisasi/pelabelan negatif kepada anak

g. Tidak mengandung unsur kekerasan verbal/psikis

5. Melalui pembiasaan berbasis karakte yang dilakukan melalui 3 (tiga) cara yaitu:

a. Pembiasaan rutin

Mengucap salam, menjawab salam, berdoa sebelum dan sesudah melakukan kegiatan, naik dan turun kendaraan, sholat dhuha, menggunakan kalimat positif dalam komunikasi dengan guru, orang tua, teman, membiasakan saling menghormati/menyayangi teman, menggunakan kalimat religius saat merespon suatu hal dan membiasakan setiap hari ada kebaikan baru yang muncul pada setiap anak.

b. Pembiasaan spontan

Pembiasaan pada peserta didik, saat akan melakukan sesuatu di tengah aktifitas pembelajaran. Contohnya meminta izin ke toilet dengan bahasa yang sopan, minta izin saat akan bertanya, minta izin saat ia memerlukan sesuatu dan lain sebagainya. Pembiasaan minta izin ini dilakukan agar santun dan teratur dalam melaksanakan suatu hal, sehingga tidak akan mengganggu peserta didik lain atau mengganggu proses pembelajaran baik di kelas maupun di luar kelas belajar.

c. Pembiasaan keteladanan;

Guru menunjukkan perilaku positif yang menginspirasi peserta didik, seperti membuang sampah pada tempatnya, bertutur kata santun, tidak "mengadili" jika ada yang bersalah. Pembiasaan keteladanan secara konsisten dilakukan melalui pembiasaan saat datang di area sekolah, pembelajaran berlangsung, pembiasaan pada saat istirahat, pembiasaan saat bermain, pembiasaan di luar kelas, serta pembiasaan di rumah melalui kemitraan bersama orang tua.

Sekolah berbasis karakter Genius Islamic School Kota Depok menerapkan seven core values atau 7 pilar karakter yang meliputi pilar religious, discipline, empathy, respect, integrity, critical thinking dan self regulated-learning. 
DAMPAK INOVASI PEMBELAJARAN BERBASIS KARAKTER TERHADAP PENGEMBANGAN ...

\section{Susanto}

Tabel 1. Pilar karakter, Kompetensi Dasar dan Indikator Pengembangan Karakter SD Karakter Genius Islamic School

\begin{tabular}{|c|c|c|c|}
\hline No & Pilar Karakter & Kompetensi Dasar & Indikator Pengembangan Karakter \\
\hline \multirow[t]{5}{*}{1} & \multirow[t]{5}{*}{ Religious } & Religion Believe & $\begin{array}{l}\text { - } \text { Beriman pada Allah, Malaikat Rasul dan } \\
\text { Kitabullah, Hari Akhir, Qada dan Qadar }\end{array}$ \\
\hline & & Religion Practice & $\begin{array}{l}\text { - } \text { Mampu Membaca } 2 \text { kalimat Syahadat } \\
\text { - } \text { Mampu menjalankan rukun Islam dalam } \\
\text { kehidupan sehari hari } \\
\text { - Terbiasa membaca doa sebelum dan sesudah } \\
\text { melakukan kegiatan } \\
\text { - Terbiasa mendoakan orang tua } \\
\text { - Terbiasa menggunakan ungkapan-ungkapan } \\
\text { - } \text { bernuansa Islam } \\
\text { Q } \text { Quran dan Al Hadis } \\
\text { Memperlihatkan kasih sayang kepada ciptaan } \\
\text { Allah }\end{array}$ \\
\hline & & Religion Feeling & $\begin{array}{l}\text { - Terbiasa mengucapkan salam dan menjawab } \\
\text { salam. } \\
\text { - Senang melakukan ibadah (shalat, sedekah, } \\
\text { berkata baik) sehari hari } \\
\text { - Senang menyanyikan lagu bernuansa Islam } \\
\text { - Senantiasa bersyukur atas nikmat Allah }\end{array}$ \\
\hline & & Religion Knowledge & $\begin{array}{ll}\text { - } & \text { Mengetahui rukun iman dan rukun Islam } \\
\text { - } & \text { Mengetahui syarat \& rukun berwudhu \& shalat } \\
\text { - } & \text { Mengetahui syarat \& rukun puasa } \\
\text { - } & \text { Mengetahui syarat \& rukun zakat } \\
\text { - } & \text { Mengenal sifat-sifat Allah } \\
\text { - } & \text { Memahami arti sifat-sifat Allah }\end{array}$ \\
\hline & & Religion Effect & $\begin{array}{l}\text { - Mampu menunjukkan sikap sabar dalam } \\
\text { kehidupan sehari-hari } \\
\text { - } \quad \text { Mampu bertutur kata yang baik } \\
\text { - Mampu menunjukkan akhlak yang baik }\end{array}$ \\
\hline \multirow[t]{3}{*}{2} & \multirow[t]{3}{*}{ Discipline } & Time & $\begin{array}{l}\text { - } \\
\text { - } \\
\text { - }\end{array}$ \\
\hline & & Rules & $\begin{array}{l}\text { - } \quad \text { Menggunakan benda sesuai dengan fungsinya } \\
\text { - } \quad \text { Mampu mentaati aturan dalam keseharian }\end{array}$ \\
\hline & & Responsibility & - Mampu melaksanakan tugas dengan baik \\
\hline
\end{tabular}


Qalamuna - Jurnal Pendidikan, Sosial, dan Agama | Vol. 13 No. 2 (2021)

\begin{tabular}{|c|c|c|c|}
\hline & & & $\begin{array}{l}\text { - Mengambil dan mengembalikan benda pada } \\
\text { tempatnya }\end{array}$ \\
\hline \multirow[t]{4}{*}{3} & \multirow[t]{4}{*}{ Empathy } & Understanding Others & $\begin{array}{ll}\text { - } & \text { Menghargai perasaan orang lain } \\
\text { - } & \text { Menenangkan teman yang merasa sedih }\end{array}$ \\
\hline & & Developing Others & $\begin{array}{l}\text { - Memberi dukungan pada teman-teman yang } \\
\text { sedang melaksanakan tugas }\end{array}$ \\
\hline & & Service Orientation & - $\quad$ Senang menolong dan membantu orang lain \\
\hline & & Leveraging Diversity & $\begin{array}{l}\text { - Mampu mengambil hikmah dari suatu kejadian } \\
\text { yang dialami }\end{array}$ \\
\hline \multirow[t]{3}{*}{4} & Respect & $\begin{array}{l}\text { Respect terhadap diri } \\
\text { sendiri }\end{array}$ & $\begin{array}{l}\text { - Mensyukuri sebagai ciptaan Allah SWT } \\
\text { - Mampu mengenali diri sendiri dan potensi diri } \\
\text { - Menjaga diri sendiri baik fisik maupun perilaku } \\
\text { - Memiliki semangat mengembangkan diri }\end{array}$ \\
\hline & & $\begin{array}{l}\text { Respect terhadap orang } \\
\text { laifn }\end{array}$ & $\begin{array}{l}\text { - } \text { Terbiasa bertutur kata santun } \\
\text { - } \text { Mengucapkan terimakasih ketika mendapatkan } \\
\text { - } \text { Memesiasi } \\
\text { - } \text { Memaafkan orang lain yang melakukan } \\
\text { - } \text { Mesalahan } \\
\text { - } \text { Mengucapakan kata permisi saat melewati } \\
\text { - } \text { Bersabar menunggu giliran bicara } \\
\text { - } \text { Mendengarkan orang lain ketika berbicara } \\
\text { - } \text { Terbiasa menghormati orang lain } \\
\text { - } \text { Menghargai pendapat orang lain } \\
\text { - } \text { Menghargai pertolongan orang lain } \\
\text { - } \text { Menghargai teman/ orang lain tanpa } \\
\text { - } \text { membedakan fisik, suku, budaya, status sosial } \\
\text { dan agama. }\end{array}$ \\
\hline & & $\begin{array}{l}\text { Respect terhadap } \\
\text { lingkungan }\end{array}$ & $\begin{array}{l}\text { - } \text { Menutup mulut ketika bersin, batuk dan } \\
\text { menguap } \\
\text { - } \text { Menjaga lingkungan sekitar } \\
\text { - } \text { Menjaga tanaman dengan baik } \\
\text { - Membuang sampah pada tempatnya } \\
\text { - Memanfaatkan air secukupnyaMenyayangi } \\
\text { hewan peliharaan }\end{array}$ \\
\hline
\end{tabular}




\begin{tabular}{|c|c|c|c|}
\hline \multirow[t]{2}{*}{5} & \multirow[t]{2}{*}{ Integrity } & Honest & 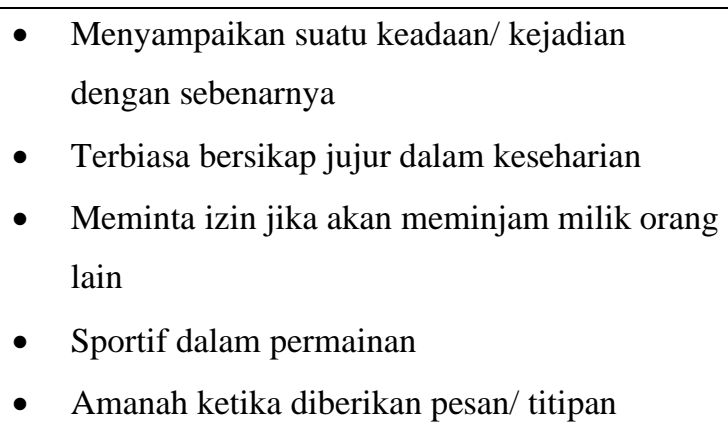 \\
\hline & & Consistence & $\begin{array}{l}\text { - } \text { Mengetahui milik pribadi, milik orang lain dan } \\
\text { milik bersama } \\
\text { - } \text { Merawat dan menjaga benda milik bersama } \\
\text { - Terbiasa mengembalikan benda yang bukan } \\
\text { miliknya } \\
\text { - } \text { Berpendirian teguh } \\
\text { Menepati janji baik ucapan maupun perbuatan }\end{array}$ \\
\hline & & Brave & $\begin{array}{l}\text { - } \text { Berani menyampaikan pendapat } \\
\text { - } \quad \text { Bersedia mengakui kesalahan }\end{array}$ \\
\hline \multirow[t]{4}{*}{6} & \multirow[t]{4}{*}{$\begin{array}{l}\text { Critical } \\
\text { thinking }\end{array}$} & Basic Thinking & $\begin{array}{l}\text { - } \quad \text { Mampu berargumentasi secara logis } \\
\text { - } \quad \text { Mampu menguraikan materi pembelajaran } \\
\text { yang telah dipelajari dengan baik }\end{array}$ \\
\hline & & Problem Solving & $\begin{array}{l}\text { - } \text { Mampu bertanya secara logis. } \\
\text { - } \quad \text { Mampu menjawab secara logis. } \\
\text { - } \quad \text { Mampu memberikan pendapat untuk } \\
\text { menyelesaikan masalah } \\
\text { - } \text { Mampu terlibat dalam menyelesaikan suatu } \\
\text { kejadian }\end{array}$ \\
\hline & & Decision Making & $\begin{array}{l}\text { - Mampu mengidentifikasi suatu kejadian } \\
\text { - } \quad \text { Mampu mengambil keputusan secara tepat }\end{array}$ \\
\hline & & Creative Thinking & 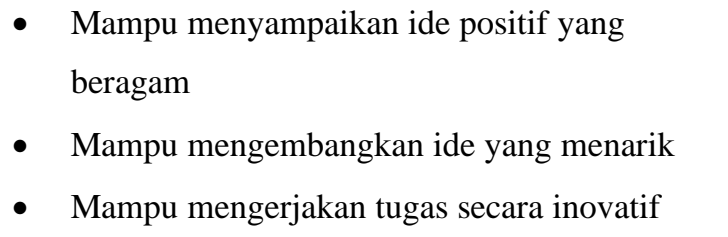 \\
\hline 7 & $\begin{array}{l}\text { Self-regulated } \\
\text { learner }\end{array}$ & Cognitive & $\begin{array}{ll}\text { - } & \text { Mampu menyusun jadwal keseharian } \\
\text { - } & \text { Mengetahui jadwal pelajaran secara mandiri } \\
\text { - } & \text { Mengetahui waktu shalat } \\
\text { - } & \text { Mengetahui waktu makan } \\
\text { - } & \text { Mengetahui waktu tidur dan bangun tidur } \\
\text { - } & \text { Mampu memilih makanan dan minuman sehat }\end{array}$ \\
\hline
\end{tabular}




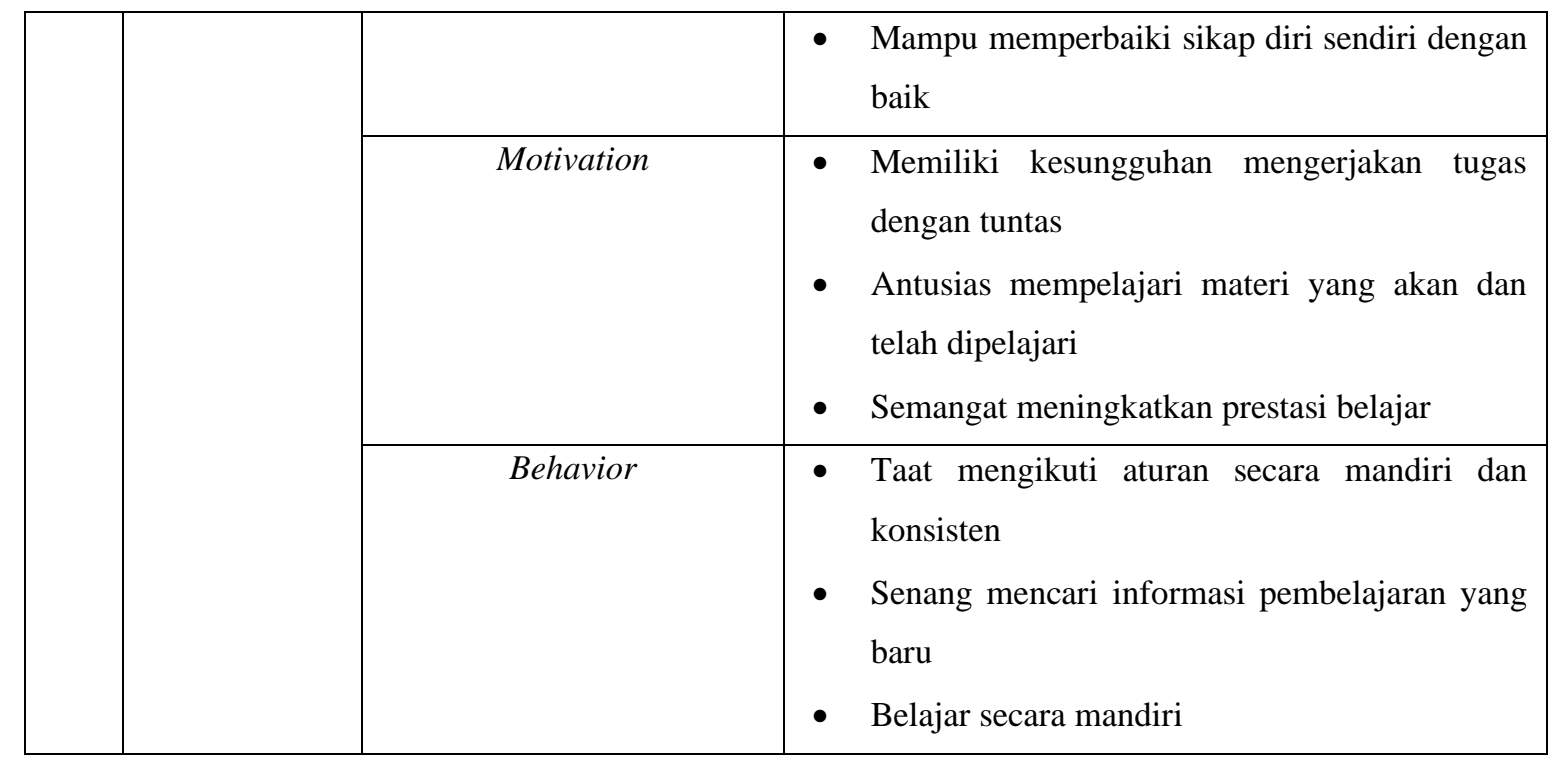

\section{Dampak Inovasi Pembelajaran Berbasis Karakter terhadap Perkembangan Karakter Positif di SD Karakter Genius Islamic School Kota Depok}

Seiring dengan inovasi-inovasi pembelajaran berbasis karakter yang dilakukan oleh SD Karakter Genius Islamic School Kota Depok menghasilkan perkembangan karakter anak sangat positif. Hasil penelitian menunjukkan capaian perkembangan karakter anak di SD Karakter Genius Islamic School seperti pada tabel berikut.

Tabel 2. Perkembangan Karakter Religious Siswa SD Karakter Genious Depok

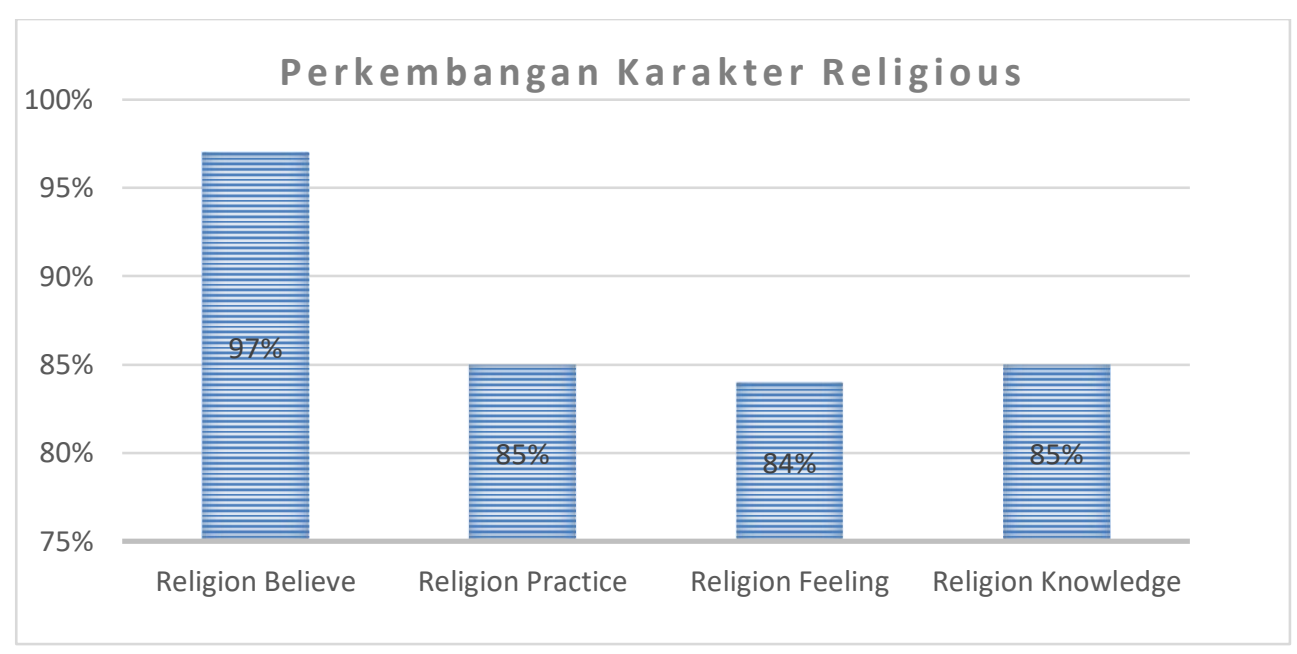

Menurut Glock and Stark tahun 1968, terdapat 5 dimensi keagamaan yang dapat diunakan untuk menganalisis kondisi karakter relogious seseorang, di antaranya sebagai berikut:

a. The belief dimension. Dimensi ini merupakan pandangan seseorang tentang seseorang yang berpegang teguh kepada ajaran agamanya dan mengakui ajaran agamanya. Misalnya, pengakuan akan adanya surga dan neraka. 
b. Religious practice. Dimensi ini mencakup praktik ibadah atau ritual keagamaan, hal tersebut dilakukan untuk menunjukkan komitmen seseorang terhadap agama yang diyakini.

c. The experience dimension. Dimensi ini berkaitan dengan pengalaman keagamaan, perasaan (feeling), pandangan seseorang dan sensasi yang dirasakan seseorang.

d. Religiuos knowledge. Dimensi ini merupakan sebuah pengharapan terhadap setiap pemeluk agama untuk memiliki pengetahuan tentang keyakinan, ritual keagamaan, kitab suci, dsb.

e. Religious consequences dimension. Dimensi ini untuk melihat sejauh mana ajaran agama berpengaruh terhadap perilaku pemeluknya.

Berdasarkan tabel di atas, dapat kita ketahui bahwa siswa SD Karakter Genius memiliki karakter religi yang sangat baik, dalam hal ini siswa SD Karakter Genius tidak hanya mengetahui ajaran-ajaran agamanya tapi juga memahami ajarannya, sehingga mendorong siswa untuk menjalankan perintah agama. Hal tersebut tentu tidak terlepas dari sebuah inovasi pembelajaran yang dikembangkan seorang guru melalui pembiasaan rutin seperti mengucap salam, menjawab salam, berdoa sebelum dan sesudah melakukan kegiatan, naik dan turun kendaraan, serta sholat dhuha. Hal ini sama dengan apa yang dikatakan oleh Gunawan, bahwa penenanaman nilai-nilai positif itu dilakukan secara bertahap dan rutin, karena dalam konsepnya karakter tidak hanya dijadikan poin dalam silabus dan perencanaan pembelajaran, akan tetapi juga harus dijalankan dan dipraktekkan. Berdasarkan data tersebut dapat disimpulkan bahwa strategi yang digunakan oleh SD Karakter Genious Islamic School memiliki hasil yang baik dalam membentuk karakter positif siswa.

Tabel 3. Perkembangan Karakter Disiplin Siswa SD Karakter Genious

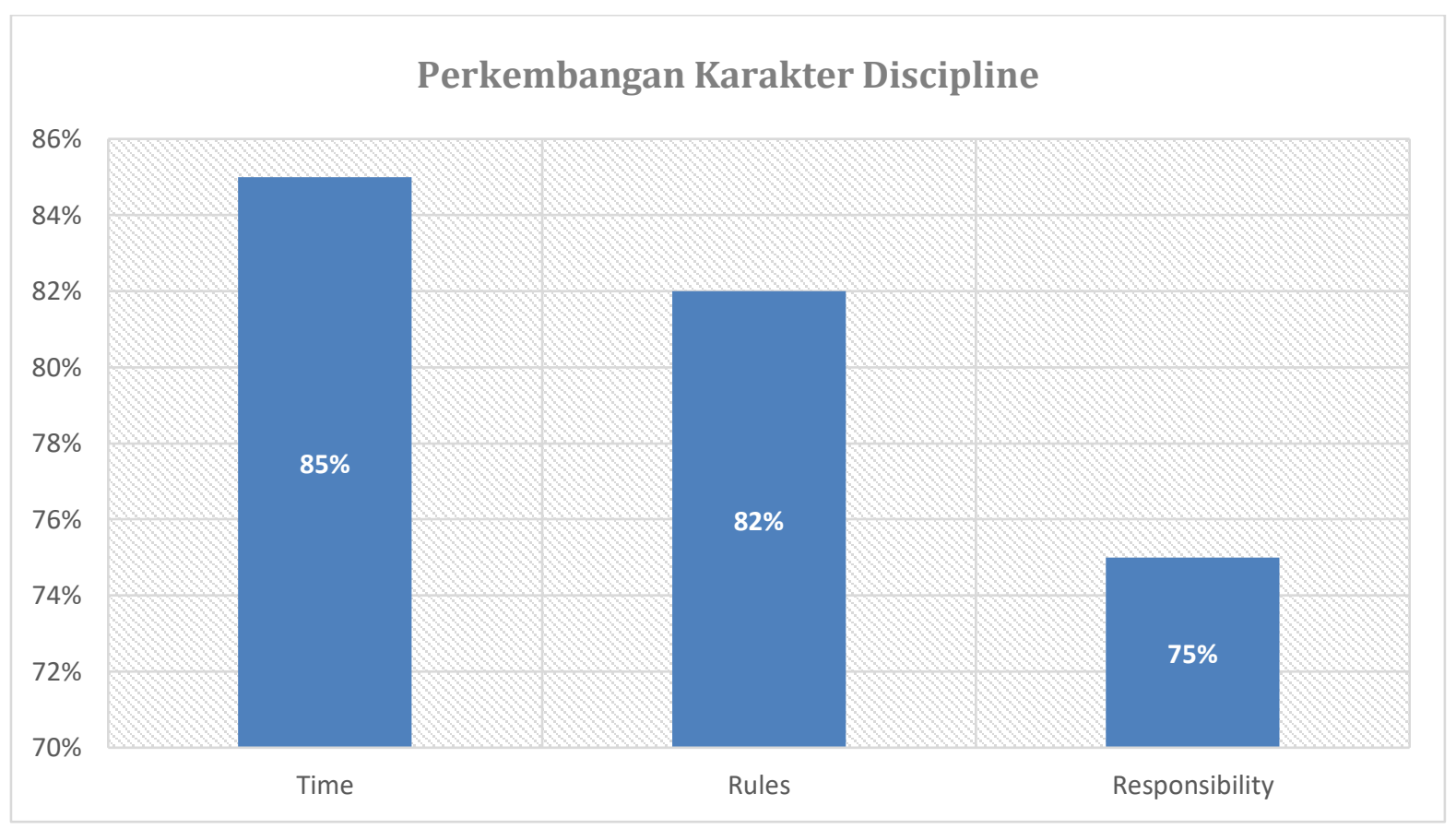


Disiplin merupakan bentuk penyerahan diri seseorang terhadap sebuah peraturan sehingga seseorang dapat menyesuaikan diri dan diterima oleh lingkungannya. Berbicara tentang kedisiplinan tentunya sikap tersebut tidak dapat tumbuh dengan sendirinya, melainkan dengan kesadaran diri, latihan, pembiasaan, dan pemberian sanksi. Hal tersebut tidak dapat dilepaskan dengan peraturan. Beberapa upaya yang dilakukan oleh SD Karakter Genius Islamic School dalam membentuk karakter disiplin siswanya adalah dengan pembiasaan keteladanan. Guru menunjukkan perilaku positif yang menginspirasi peserta didik, seperti membuang sampah pada tempatnya, kemudian pembiasaan keteladanan secara konsisten dilakukan melalui pembiasaan saat datang di area sekolah, pembelajaran berlangsung, pembiasaan pada saat istirahat, pembiasaan saat bermain, pembiasaan di luar kelas, serta pembiasaan di rumah melalui kemitraan bersama orang tua.

Berdasarkan pada tabel di atas dapat dikatakan bahwa inovasi pembelajaran dalam meningkatkan karakter positif berdampak sangat baik dalam meningkatkan kedisiplinan siswa. Dari segi disiplin waktu, siswa tepat waktu ketika datang ke sekolah, tepat waktu dalam mengerjakan tugas, dan mampu mentaati peraturan sekolah.

Tabel 4. Perkembangan Karakter Emphaty Siswa SD Karakter Genious

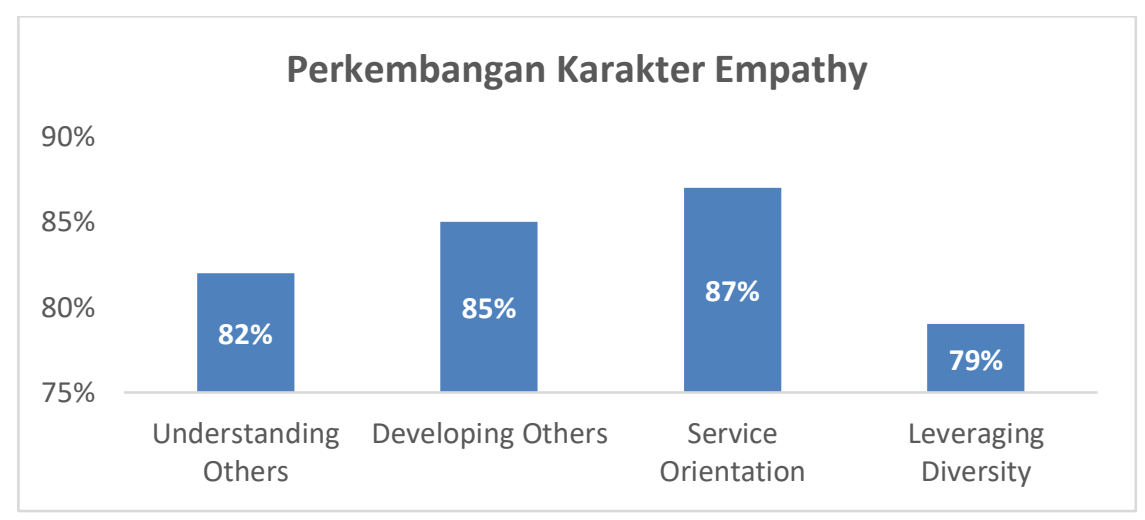

Berdasarkan tabel di atas tentang perkembangan karakter emphaty SD Karakter Genious Depok dapat dikatakan sangat baik. Dengan indikator bahwa siswa di sana dapat menghargai perasaan orang lain, menenangkan teman yang merasa sedih, memberi dukungan pada teman-teman yang sedang melaksanakan tugas, senang menolong dan membantu orang lain, dan mampu mengambil hikmah dari suatu kejadian yang dialami. Empati merupakan salah satu bagian penting dalam kepribadian seseorang yang di dalamnya mencakup unsur moral intelligence dan emosional intelligence. Selain itu, empati merupakan bagian penting dari perilaku sosial seseorang (Arthur et al., 2015). Goleman menyatakan, empati merupakan kemampuan seseorang untuk mengetahui dan memahami bagaimana perasaan orang lain. Kunci untuk memahami perasaan orang lain adalah dengan kemampuan dalam membaca pesan non verbal, nada bicara, gerak gerik, dan ekspresi wajah yang nampak saat seseorang mengungkapkan perasaannya (Andrianie et al., 2017). 
Tabel 5. Perkembangan Karakter Respect Siswa SD Karakter Genious

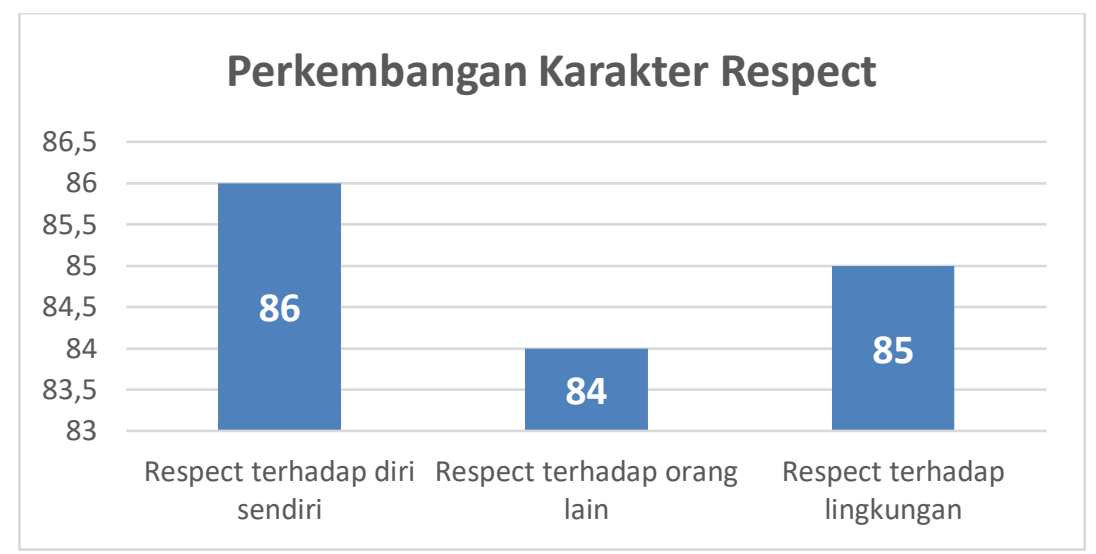

Respect merupakan sikap menghargai dan menghormati orang lain. Akhir-akhir ini, karakter respek dalam diri seseorang nampak mulai mengalami penurunan. Hal ini dapat dilihat dari banyaknya kasus-kasus yang terjadi pada generasi muda. Berdasarkan hasil wawancara yang dilakukan oleh Sangaji di SDN Gadingkasri pada tahun 2019, diperoleh data bahwa menurunnya karakter respek siswa terlihat pada kasus siswa yang mengolok-olok teman hingga menjadikan nama orang tua sebagai bahan olokan, tidak menyimak penjelasan guru di kelas, dan pemalakan antar siswa. Pada akhir tahun 2018, terjadi pengeroyokan oleh siswa di salah satu sekolah di Kediri, penyebabnya adalah gol bunuh diri saat bermain sepak bola pada jam istirahat. Pada tahun yang sama, terjadi perkelahian oleh siswa salah satu sekolah di Garut, hingga menewaskan salah satu siswa. Jika tidak ada upaya preventif yang dilakukan, maka tidak menutup kemungkinan kasus-kasus menurunnya kesadaran respek akan terus bertambah (Safitri et al., 2021). Maka dari itu, dalam upaya preventif terhadap kejadian-kejadian tersebut, SD Karakter Genius Islamic School menelurkan sebuah strategi yang disebut dengan strategi komunikasi berwawasan karakter. Berdasarkan hasil survei karakter respect terbentuk dengan baik dengan prosentase respect terhadap diri sendiri sebesar $86 \%$, respect terhadap orang lain $84 \%$, dan respect terhadap lingkungan sebesar $85 \%$.

Tabel 6. Perkembangan Integrity Siswa SD Karakter Genious

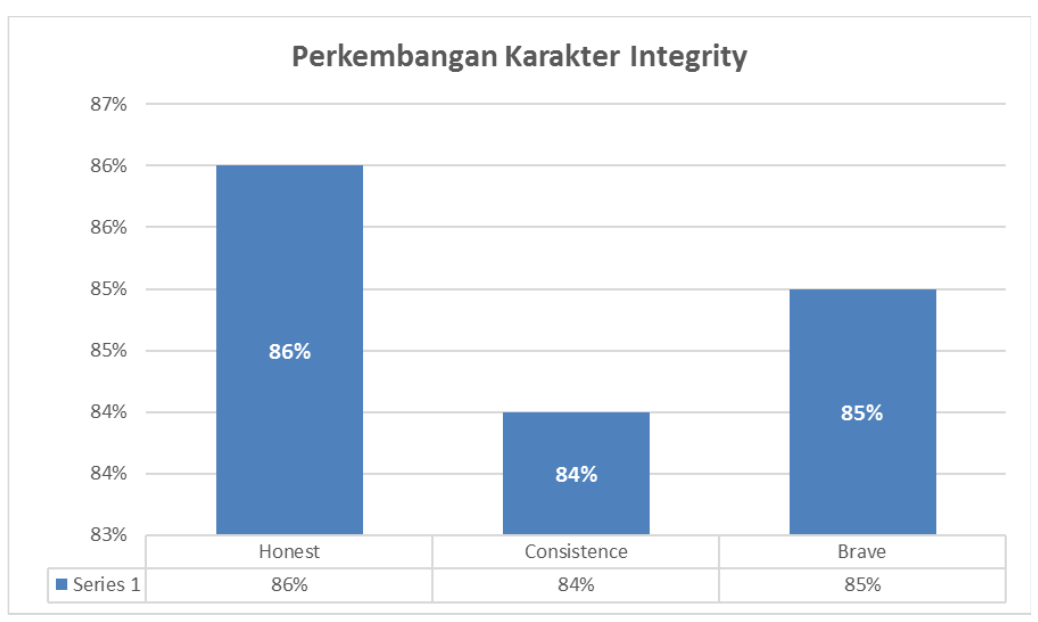


Karakter integritas merupakan dasar perilaku pada upaya menjadikan seseorang yang selalu dapat dipercaya dalam perkataan, tindakan, dan pekerjaan, serta memiliki komitmen dan kesetiaan pada nilai-nilai kemanusiaan, moral, atau integritas moral. Karakter integritas meliputi sikap tanggung jawab sebagai warga negara, aktif terlibat dalam kehidupan sosial, serta konsistensi dalam tindakan dan perkataan yang berdasarkan kebenaran. Nilai integritas, antara lain, kejujuran, cinta pada kebenaran, setia, komitmen moral, anti korupsi, keadilan, tanggung jawab, keteladanan, dan menghargai martabat individu (Komara, 2018).

Berdasarkan hasil survei, karakter integrity yang ditanamkan kepada siswa SD Karakter Genius Islamic School berdampak positif dengan kisaran 84-86 persen, dengan indikator siswa dapat menyampaikan suatu keadaan/kejadian dengan sebenarnya, terbiasa bersikap jujur dalam keseharian, meminta izin jika akan meminjam milik orang lain, sportif dalam permainan, amanah ketika menyampaikan pesan/titipan, mengetahui milik pribadi, milik orang lain dan milik bersama, merawat dan menjaga benda milik bersama, terbiasa mengembalikan benda yang bukan miliknya, berpendirian teguh, menepati janji baik ucapan maupun perbuatan, berani menyampaikan pendapat, dan bersedia mengakui kesalahan.

Tabel 7. Perkembangan Karakter Critical Thinking Siswa SD Karakter Genious

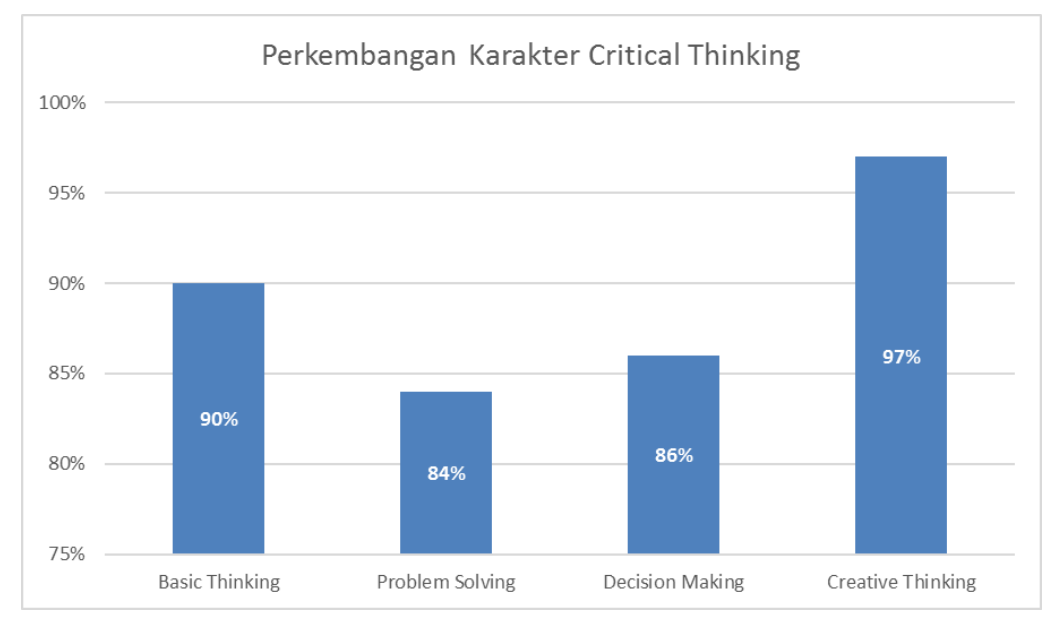

Critical thinking menurut Kennedy adalah sebagai "enable people to evaluate, compare, analyze, critique, and synthesize information”. Secara garis besar pendapat Ennis dan Kennedy tentang critical thinking adalah pemikiran yang beralasan dan reflektif dengan mempertahankan apa yang dikerjakan atau dipercaya dengan memakai teknik seperti mengevaluasi membandingkan, menganalisa, mengkritik, hingga siap menyajikan informasi.

Berdasarkan hasil survei dapat ketahui bahwa pembentukan karakter Critical thinking mendapatkan hasil paling tinggi diantara karakter lainnya dengan perolehan prosentase tertinggi dalam aspek creative thinking mencapai $97 \%$. Berdasarkan indikator yang ada dapat disimpulkan 
bahwa siswa SD Karakter Genius Islamic School telah mampu menyampaikan ide positif yang beragam, mampu mengembangkan ide yang menarik, serta mampu mengerjakan tugas secara inovatif.

Tabel 8. Perkembangan Karakter Self-Regulated Learning Siswa SD Karakter Genious

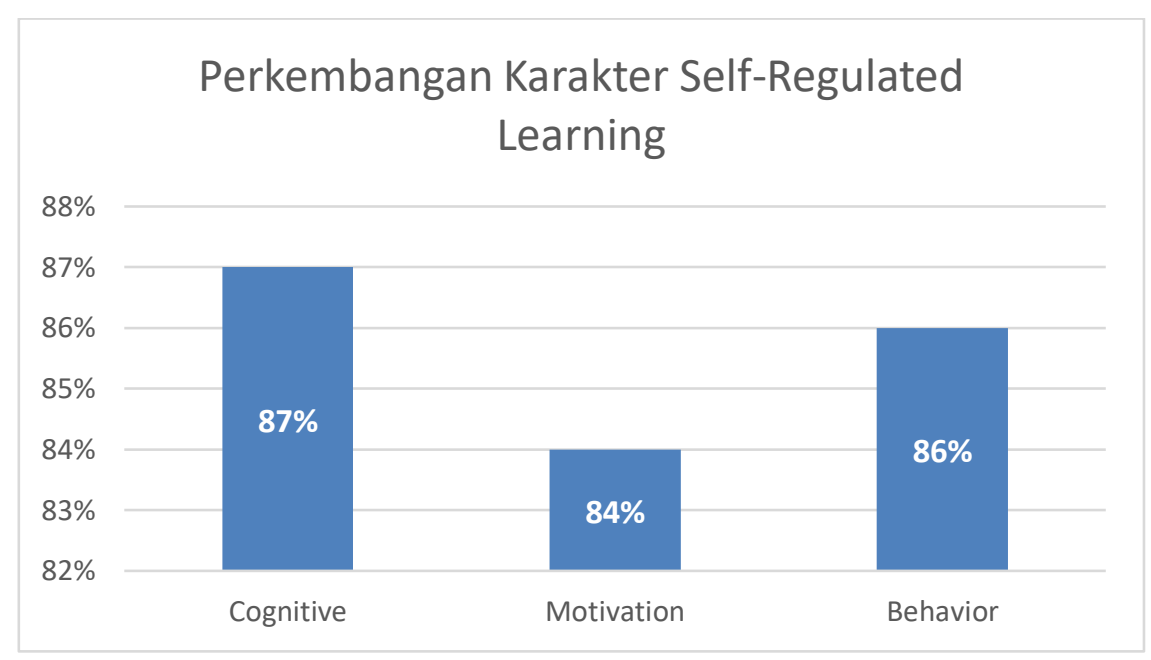

Self-Regulated Learning atau SLR dapat disebut sebagai manajemen diri, dalam artian seorang siswa mampu mengatur waktu belajarnya secara mandiri, mampu mengevaluasi diri sendiri, mampu menyadari kekurangan, mempunyai semangat belajar dan semangat dalam menyelesaikan tugastugasnya, mematuhi peraturan tanpa paksaan dari orang lain, dan belajar hal-hal yang baru. Berdasarkan hasil survei yang ditampilkan dalam tabel dapat kita lihat bahwa 5 strategi yang digunakan dalam pengembangan Self-Regulated Learning memiliki hasil yang baik.

\section{KESIMPULAN}

Inovasi pembelajaran berbasis karakter yang dikembangkan oleh SD Karakter Genius Islamic School dilakukan dengan berbagai upaya, yakni: a) mengintegrasikan dengan beberapa mata pelajaran secara tematik seperti Islamic studies, tahfidz, science, english, mathematic dan Bahasa Sunda baik secara eksplisit maupun implisit; b) Integrasi karakter positif melalui pemilihan metode yang edutainment berwawasan karakter; c) Melalui character education selama 10 menit dalam rangkaian apersepsi yang mengandung muatan 7 pilar karakter yang dikembangkan di SD Genius Islamic School. Character education ini diberikan kepada anak sebelum materi pembelajaran berlangsung. Selanjutnya, guru memberikan materi character education selama 10 menit melalui berbagai strategi, diantaranya melalui video karakter disesuaikan dengan jadwal pilar karakter melalui diskusi problem solving, studi kasus dan berbagai metode lainnya; d). Melalui pembiasaan berbasis karakter. 
Strategi pembiasaan dilakukan melalui 3 (tiga) cara pembiasaan, yaitu pembiasaan rutin dalam mengucap salam, menjawab salam, berdoa sebelum dan sesudah melakukan kegiatan, naik dan turun kendaraan, salat dhuha, menggunakan kalimat positif dalam komunikasi dengan guru, orang tuaa dan teman, membiasakan saling menghormati/menyayangi teman, menggunakan kalimat religi saat merespon suatu hal dan membiasakan setiap hari ada kebaikan baru yang muncul pada setiap anak. Melakukan pembiasaan spontan peserta didik saat akan melakukan sesuatu di tengah aktifitas pembelajaran. Contohnya, meminta izin ke toilet dengan bahasa yang sopan, minta izin saat akan bertanya, minta izin saat ia memerlukan sesuatu dan lain sebagainya. Pembiasaan minta izin ini dilakukan agar santun dan teratur dalam melaksanakan suatu hal, sehingga tidak akan mengganggu peserta didik lain atau mengganggu proses pembelajaran baik di kelas maupun di luar kelas belajar. Pembiasaan keteladanan oleh guru seperti menunjukkan perilaku positif yang menginspirasi peserta didik, membuang sampah pada tempatnya, bertutur kata santun, tidak "mengadili” jika ada bersalah. Pembiasaan keteladanan secara konsisten dilakukan melalui pembiasaan saat datang di area sekolah, pembelajaran berlangsung, pembiasaan pada saat istirahat, pembiasaan saat bermain, pembiasaan diluar kelas serta pembiasaan di rumah melalui kemitraan bersama orang tua.

Melalui upaya-upaya tersebut ternyata inovasi pembelajaran berbasis karakter di SD Karakter Genius Islamic School ternyata memiliki dampak yang baik dalam membentuk karakter positif siswa dengan hasil tertinggi 97\% dalam pengembangan karakter Religion Belief dan Creative Thinking. Dengan demikian dapat diartikan bahwa para siswa memegang teguh ajaran agamanya dan mampu menyampaikan ide serta berfikir kreatif sehingga menghasilkan karya yang inovatif. Sedangkan tingkat keberhasilan nilai-nilai karakter yang lain mencapai hasil 85\%.

\section{DAFTAR PUSTAKA}

Abu, L., Mokhtar, M., Hassan, Z., \& Suhan, S. Z. D. (2015). How to develop character education of madrassa students in Indonesia. Journal of Education and Learning, 9(1), 79-86.

Andrianie, S., Ariyanto, R. D., \& Nawantara, R. D. (2017). Peningkatan Keterampilan Empati sebagai Usaha Pembentukan Generasi Karakter. Seminar Nasional Bimbingan Konseling Universitas Ahmad Dahlan, 2.

Arthur, J., Kristjánsson, K., Walker, D., Sanderse, W., \& Jones, C. (2015). Character education in UK schools.

Azra, A. (2019). Pendidikan Islam: tradisi dan modernisasi di tengah tantangan milenium III. Prenada Media. 
Danim, S. (2002). Inovasi pendidikan: dalam upaya peningkatan profesionalisme tenaga kependidikan.

Djazilan, S., Nafiah, N., \& Hartatik, S. (2021). Implementasi Pendidikan Karakter Integritas Sub Nilai Kejujuran melalui Program Kantin Kejujuran di Sekolah Dasar. EDUKATIF: Jurnal Ilmu Pendidikan, 3(6), 3565-3578.

Eka, E. (2017). Revisiting Character Education from Islamic Perspective: A Quest for Characterbased Education in Indonesia. Ulumuna, 21(1), 1-33.

Fahmi, M., \& Prasetia, S. A. (2021). Quo Vadis Pendidikan Karakter di Indonesia. TABYIN: JURNAL PENDIDIKAN ISLAM, 3(01), 23-45.

Faujiah, A., Tafsir, A., \& Sumadi, S. (2018). Pengembangan Karakter Anak Di Indonesia Heritage Foundation (Ihf) Depok. Jurnal Penelitian Pendidikan Islam,[SL], 6(2), 163-186.

Genius Islamic School. (2021). Profil SD Karakter Genius Islamic School. https://geniusislamicschool.sch.id/

Gunawan, H. (2012). Pendidikan karakter. Bandung: Alfabeta, 2(1).

Hartono, Y., Haryanto, S., \& Asrowi, A. (2018). Character education in the perspective of humanistic theory: A case study in Indonesia. EDUCARE, 10(2).

Hidayat, S. (2016). Menanamkan Nilai-nilai Karakter melalui Inovasi Pembelajaran Berbasis Karakter dalam Menghadapi Masyarakat Ekonomi ASEAN. Prosiding Seminar Nasional Inovasi Pendidikan.

Husni, H. (2020). Character education in Indonesia: a historical outlook. Educational Review: International Journal, 17(1), 147-162.

Izzati, U. A., Bachri, B. S., Sahid, M., \& Indriani, D. E. (2019). Character education: Gender differences in moral knowing, moral feeling, and moral action in elementary schools in Indonesia. Journal for the Education of Gifted Young Scientists, 7(3), 547-556.

Judiani, S. (2010). Implementasi pendidikan karakter di sekolah dasar melalui penguatan pelaksanaan kurikulum. Jurnal Pendidikan Dan Kebudayaan, 16(9), 280-289.

Julaeha, S. (2019). Problematika Kurikulum Dan Pembelajaran Pendidikan Karakter. Jurnal Penelitian Pendidikan Islam, [SL], 7(2), 157-182.

Kemendiknas, R. I. (2010). Disain Induk Pendidikan Karakter. Jakarta.

Khusniati, M. (2012). Pendidikan karakter melalui pembelajaran IPA. Jurnal Pendidikan IPA 
Indonesia, 1(2).

Komara, E. (2018). Penguatan pendidikan karakter dan pembelajaran abad 21. Sipatahoenan, 4(1).

Marzuki, M. A. (2012). Pengintegrasian Pendidikan Karakter Dalam Pembelajaran Di Sekolah. Jurnal Pendidikan Karakter,(1).

Murniyetti, M., Engkizar, E., \& Anwar, F. (2016). Pola pelaksanaan pendidikan karakter terhadap siswa sekolah dasar. Jurnal Pendidikan Karakter, 6(2).

Ningsih, T., Zamroni, Z., \& Zuchdi, D. (2015). Implementasi pendidikan karakter di SMP Negeri 8 dan SMP Negeri 9 Purwokerto. Jurnal Pembangunan Pendidikan: Fondasi Dan Aplikasi, 3(2), $225-236$.

Rasna, I. W., \& Tantra, D. K. (2017). Reconstruction of local wisdom for character education through the Indonesia language learning: An ethno-pedagogical methodology. Theory and Practice in Language Studies, 7(12), 1229-1235.

Revell, L., \& Arthur, J. (2007). Character education in schools and the education of teachers. Journal of Moral Education, 36(1), 79-92.

Safitri, I. F., Handarini, D. M., \& Mappiare-AT, A. (2021). Meningkatkan Kesadaran Respek Siswa Sekolah Dasar dengan Biblioedukasi. Buletin Konseling Inovatif/Bulletin of Innovative Counseling, 1(1).

Saidek, A. R., \& Islami, R. (2016). Character Issues: Reality Character Problems and Solutions through Education in Indonesia. Journal of Education and Practice, 7(17), 158-165.

Sani, R. A. (2013). Inovasi pembelajaran. Jakarta: Bumi Aksara.

Suharsaputra, U. (2010). Administrasi pendidikan. Bandung: Refika Aditama.

Suherman, A., Supriyadi, T., \& Cukarso, S. H. I. (2019). Strengthening national character education through physical education: An action research in Indonesia. International Journal of Learning, Teaching and Educational Research, 18(11), 125-153.

Sulistyowati, E. (2012). Implementasi kurikulum pendidikan karakter. Yogyakarta: Citra Aji Parama, 12.

Supriati, A., \& Umar, M. (2018). Optimization of the Civic Education as the Effort to Strengthen National Character in Multicultural Community.

Suwardani, N. P. (2020). “QUO VADIS” PENDIDIKAN KARAKTER: dalam Merajut Harapan Bangsa yang Bermartabat. Unhi Press. 
Tafsir, A. (2009). Pendidikan Budi Pekerti. Bandung: Maestro.

Tutuk, N. (2015). Implementasi pendidikan karakter.

Zuchdi, D., Prasetya, Z. K., \& Masruri, M. S. (2010). Laporan penelitian hibah penelitian tim pasca sarjana: pengembangan mdel pendidikan karakter terintegrasi dalam pembelajaran bidang studi di sekolah dasar. Yogyakarta: Program Pasca Sarjana UNY. 